\title{
MANAGING NEO-LIBERALISM AND THE STRONG STATE IN HIGHER EDUCATION: PSYCHOLOGY TODAY
}

\begin{abstract}
This paper locates significant changes in the discipline of psychology in recent years in the context of transformations of higher education that are in turn a function of the emergence of 'neoliberal' capitalism which deregulates welfare and education services and places responsibility on the individual. The paper reviews theoretical resources - from Marxism, post-structuralist theories of power, and feminism - and brings them to bear on narratives of the 'paradigm revolution' in psychology - the attempt to shift research from laboratoryexperimental method to a qualitative approach attentive to meaning and experience. These debates can now seen to resonate with deeper political-economic changes which have taken place at the level of institutional management practices and subjectivity, changes which are profoundly gendered in line with the neoliberal emphasis on 'emotional labour'. The paper concludes with an account of the consequences for experience, rhetoric, affect and self-abasement in these neoliberal conditions, and for how we might understand the role of 'psychologisation' in critical psychology, qualitative research and the broader culture.
\end{abstract}

\section{Keywords}

Psychology, qualitative research, critical psychology, neoliberalism, gender, power

\section{Introduction}

A 'paradigm revolution' promised for psychology in the 1970s was viewed by its advocates as entailing a shift from laboratory-experimental quantitative research to a qualitative 'new paradigm' (Harré and Secord, 1972). Now, while the terms of the debate have mutated into an argument for 'critical psychology', we have seen a transformation of the cultural-political landscape in which psychology operates. The university as an institution has been subject to neo-liberal reforms, with an intensification of surveillance and control at the same time as there is an intensification of interest in individual subjectivity. A concern with 'quantity' in research is now augmented by an attention to 'quality' in the service of power, something which is described by management as part of a 'change agenda'.

The starting assumption in this paper is that if we want to do critical work in psychology we need to attend to the conditions in which we do that work. This paper is concerned with the institutional conditions that frame what we are able to do, and the way those institutional 'conditions of possibility' for psychology shape how we speak about, and even think and feel about the possibility of critical work in the discipline.

Most of what we now call 'critical psychology' takes place in higher education institutions, in universities and colleges of different kinds (Gough et al., 2013; Parker, 2011). It is that academic space that we will be focused on, and the paper will give some examples from a particular academic space in Britain that is indicative of some broader institutional processes (Levidow, 2002; Lynch, 2006). The processes described are in some ways more intense in the further education sector, and in what would be called 'community colleges' in some countries. 
Critical psychologists have tried to connect their academic work with that of professional psychologists and, of course, with users of psychology services, and there are implications of this work for those other spheres of work. The balance between public and private higher education provision is different in different places, and the impact of neoliberalism has been greater in some places outside Britain, so this account will have some resonance with colleagues there (Torres and Schugerensky, 2002; Zajda, 2005).

Some aspects of those conditions are immediately apparent to anyone working in a psychology department today. But most of the time individuals protect themselves by subscribing to what Alfred Sohn-Rethel (1978) calls the 'necessary false consciousness' that things are as they should be, that there is no alternative. This phrase 'necessary false consciousness' is designed to emphasise that we are not mistaken or deluded by ideological systems, but rather we need to inhabit them, live them, feel them, in order to get along and survive in this world.

It is unbearable to know all of the time how bad things are and, at the same time, to speak and perform as if what we must say is unproblematic. Of course, there are many who are marginalised, pushed to the edge for different reasons, those who for reasons of gender, sex, race, for example, experience that impossibility, who live in what W.E.B. Du Bois (1994) called a 'double consciousness' of their oppression and their ascribed identity (something that should not be confused with the psychologised notion of 'divided consciousness' discussed by Hilgard, 1977).

There are spaces from which it is possible to reflect on what is wrong, such as political organisations in or on the edge of the institution. I will include in this account some auto-ethnographical reflections (Ellis and Bochner, 2000) to make the point. In late 2012 I was involved in dispute with management in my university. I spoke from the position of trade union representative, questioning secrecy and control in my institution, and what happened next opened up the machinery of the institution. It was as if, when I was contacted by colleagues in my university and in many other places in Britain and other countries with their own similar stories, I could see into the apparatus, as if I was faced with something that was usually easier to keep out of sight, out of awareness.

Now that idea that we could all together see things more clearly, just as they were, is equally illusory, and that idea can too easily then spin into a rather conspiratorial and paranoiac image of the world of higher education. The sense that 'they' are out to get you, that they have immense power, that they will win, is not ameliorated by the idea that international solidarity will save you. The two sides of the equation are twinned with each other, reinforce each other.

In that kind of situation, when it is most tempting to go with what you know, with your immediate impression of what you are up against, it is most important to use theoretical frameworks to interpret it. Then it is more important than ever to locate what is happening here, to you, in broader context, to conceptualise what is going on.

So the first assumption I am making, one that already has implications for our take on critical psychology, is that we need theory in our work because our reality is always mediated. 


\section{Theoretical resources}

I was lucky to have good signposts to theory as well as advice during the campaign to support me (and an archive of material with links to key documents and political analysis of the case is available at www.parkerian.com/asylum).

My trade union and political comrades, of course, knew that what we were experiencing was a manifestation of the latest crisis of capitalism. The attempt by management to extract more surplus value from our labour in times of competition between universities for undergraduate students is now set against the background of privatisation and deregulation of welfare support or entitlement to education (Callinicos, 2006). That political-economic background is what we call 'neoliberalism', and I will say more about what that means in a moment.

For the moment, an indication is given by a former advisor to the last Labour government that pushed ahead with so many neoliberal 'reforms' in UK Higher Education. They put it like this: 'Universities should become not just centres of teaching and research but hubs for innovation networks in local economies, helping spin off companies for universities, for example. Universities should be the open-cast mines of the knowledge economy' (Leadbeater, 2000, p. 114). It is there that we also have to appreciate the importance of the 'strong state' as an inevitable complement of neoliberal ideologies of individual freedom in the market-place.

There were also some good points in the many hundreds of letters of support to the university that highlighted theoretical frameworks that we need to take seriously in any analysis of the dialectical interplay between surveillance and subjectivity under neoliberalism. One letter included the question to the Vice-Chancellor 'Is this really the best way to put in place control measures of [sic] staff who won't stay quiet in the face of an onslaught of disciplinarity?', and it continued 'If you ask me, you should go and read Foucault on "governmentality" if you haven't already, and, if you have, read it again, because you obviously didn't understand it the first time around!' Well said, and, yes, Foucault $(1976,1981)$ has to be there in the mix to make sense of what has been happening to get at the intimate connection between power and affect.

The day after I saw that a hand-written card to me and my partner reminded us of the relevance of the work of the Black feminist activist and writer Audre Lorde, with some great quotes from her essay 'The transformation of silence into language and action' where she says 'Your silence will not protect you', and asks 'what are the words you do not yet have? What do you need to say? What are the tyrannies you swallow day by day and attempt to make your own, until you will sicken and die of them still in silence' (Lorde, 2007, p. 41). Now this perspective, of course, brings into the equation a question about 'voice' which we need to include not as the opposite of theory but as its condition and consequence (Collins, 2000).

So, we have at least three different kinds of theoretical resource, and I want to put them to work to address four aspects of the problem, the conditions of possibility for us to do critical psychology today. I will refer to these four aspects as if they are layers of the problem, with the twist that the third and four layer loop around and enclose each other.

The first is the broad cultural-political-economic context for the transformations that have been occurring in higher education, context which includes the kind of colonial expansion and internal differentiation of markets that sometimes are neatly described as 
'glocalisation' (Robertson, 1995). The second layer is in the institutional response by universities as they subordinate themselves to the market and manage that process through what is, in some places, called the 'change agenda' (e.g., http://www2.mmu.ac.uk/about/vision/).

The third layer is psychology. It is where we are here, which is somewhere in or in relation to the discipline of psychology and trying to make that place into something we might like to call 'critical psychology'. The fourth layer is our critical reflection on psychology. It is what we are doing now as we try to make sense of what is going on, as we try to make our critical psychology resistant to those first three layers. We draw on conceptual and methodological resources from qualitative and discursive psychology and find that sometimes it might be colluding with them, becoming part of the problem. I will unpack that question of collusion, of being part of the problem later.

\section{Three shifts}

There have been some significant changes in psychology in the last forty years or so, and those changes have opened a space for 'critical psychology' to emerge as a perspective that is taken seriously in some departments. Critical psychology comprises a wide range of critiques of mainstream psychology and new theories and methodologies which include, but which are not restricted to developments in qualitative research (Parker, 2011). It shifts the focus of psychological research toward the 'social' dimension of human action, and that enables it to attend to questions of language and power (Gough et al., 2013; Hepburn, 2002)

We should not overplay the strength of critical psychology though, and psychology departments in Britain, at least, tend to be run like seaside zoos where it is useful to have one or two of everything. Those who are seen as offering alternatives to the old paradigm laboratory-experimental approach are expected to cover critical psychology, qualitative methods, feminist psychology, community psychology and so on. That means that some important differences of perspective between those approaches are obscured, and feminist psychologists, for example, are still often marginalised (Burman, 1990, 1998).

More important still, however, is the way that the so-called 'paradigm revolution' which began in the 1970s has intersected with the triumph of neoliberalism over roughly the same period, and then with what in some spheres of management in higher education is called the 'change agenda'. Let us look briefly at the paradigm shift narrative before situating it in the context of neoliberalism and management strategy.

\section{Paradigm shifts}

This is the story... Laboratory-experimental method provided the dominant scientific paradigm in the discipline of psychology until the late 1960s, but as with other periods of 'normal science' described by Thomas Kuhn (1962) in his book The Structure of Scientific Revolutions, there was an increasing number of anomalies thrown up by research in this old paradigm.

The subjects in psychology experiments kept trying to guess what the hypothesis being tested was, for example, and the more this active reflexive activity was controlled for the less 'ecologically valid' the results became (Neisser, 1976). (On misuses of the term 'ecological validity', see Hammond, 1998.) The resulting paradigm shift needed to be as dramatic as the shift of perspective in astronomy in Galileo's time that opened up a new 
way of interpreting the old data and of doing new research. The new paradigm in social psychology would 'for scientific purposes treat people as if they were human beings' (Harré and Secord, 1972, p. 84), human beings as speaking beings.

Even if researchers in the wake of the 'new paradigm' did not often take the phrase 'for scientific purposes' so seriously, they did pick up the idea that roles and rules as linguistic resources were crucial to psychology, and then approaches like thematic analysis and discourse analysis took things forward in their own ways (Banister et al., 1994, 2011).

The 'linguistic' turn was quickly transformed into a 'discursive turn', and somewhere along the way the 'paradigm revolution' arguments that opened a space for these new approaches disappeared into the background. Perhaps they had done their work, perhaps they operated as the kind of catalyst for change that is itself then forgotten, what Fredric Jameson (1988) has termed a 'vanishing mediator'.

Now, many readers will be saying to themselves that it did not happen exactly like that, it was more complicated, with many other strands of argument and debates, not to mention the fact that the paradigm revolution failed. That is, the laboratory-experimental way of doing things is still very much in charge in most psychology departments, and those of us who want to treat people as if they were human beings are still kicking around on the margins.

In Britain, for example, most 'critical psychology' is not counted in the Research Assessment Exercises that happen across the university sector every five or six years. In the last assessment and in the next, grandly called the Research Excellence Framework, most of us 'criticals' were entered with sociology or education. Some critical researchers have pretty much abandoned the field of psychology, preferring to work under the label of, say, 'psychosocial studies', and there have even been splits in some universities where the psychosocial people have left to set up their own department.

So, yes, there were other things going on, other stories told, and we need to unravel that paradigm shift narrative a bit, do a kind of analysis of it that does not simply treat it as a 'discourse' or collection of discourses, but as a contradictory narrative that is institutionallylocated. It happened in material political-economic circumstances that give certain aspects of it a peculiar uncanny valence now, unanticipated effects. As Foucault once said, 'People know what they do, they frequently know why they do what they do, but what they don't know is what they do does' (cited in Dreyfus and Rabinow, 1983, p. 187). For all of the poststructuralist attempts to dissolve subjectivity into the play of discourses, Foucault's point is necessary to hold onto here for two reasons: first, that we do not treat social actors as dupes of a series of social processes that they do not, and could not grasp; second, that we hold those who are obedient to power and are then willing to subject others to that power are held to account for what they have done. Foucault's argument here enables us to take a distance from any kind of economic or discursive determinism and calls upon us to take responsibility for our actions.

Let us take three issues concerning what was done and what the effects were from inside this narrative, from inside its tangle of contradictions, which pose some puzzles that political-economic and institutional power relations will unfortunately provide solutions for. They each actually revolve around that question of 'for scientific purposes' that was supposed to capture the imagination of psychologists and persuade them to move from one paradigm to another. 
What goes round what? The first concerns that tactical use of the notion of a 'paradigm revolution' from Thomas Kuhn, and rhetorical force of the Copernican shift essential to Galileo's own argument, that the sun does not go around the earth, rather that the earth goes around the sun. Now, on the one hand, the parallel between these two kinds of supposed 'paradigm revolution' - a phrase that has multiple meanings in Kuhn's work (Masterson, 1970) - makes sense, for one mode of observation (through the apparatus of the laboratory-experiment) was being replaced by another. We do not now see things just as there, but through a different series of research procedures, just as Galileo had to persuade astronomers to look through telescopes to see the moon in a different way as one of a number of planets circling the sun.

On the other hand, there was a rhetorical appeal to the 'new paradigm' argument that did make it seem like the old paradigm distorted things, and now we could align what we saw with what we knew about people. Just as Galileo wrote in Italian rather than Latin to reach beyond an enclosed rigid academic community (Feyerabend, 1978), so some 'new paradigm' arguments became harnessed to rather simplistic humanist opposition to psychologists treating their subjects like objects. It was as if science should be replaced by nice commonsense.

The problem here is not only that many mainstream psychologists shrank back from this because they do want to be scientists, but that the commonsensical discourses about what science and what commonsense is are themselves saturated with ideology. Actually, the Copernican revolution displaced the human being from the centre of the universe.

One direction the new paradigm should logically have taken us in would be to a questioning of what the human subject is when it is no longer the centre of creation, no longer the ideal humanist subject. Some forms of discourse analysis went along that road, and some connections have then been made with psychoanalysis (Pavón Cuéllar, 2010). Whether that is a good or a bad thing is something we need to address another time.

The point is that instead of a questioning of human agency and the conditions in which it operates - 'understanding what we do does' as Foucault might have put it - we end up with some forms of qualitative research in psychology today that celebrate human agency and overlook what political-economic and institutional structures condition it.

Who is speaking to who? The second issue concerning the gap between what was done and what the effects were concerns what new forms of power might be coming into play when we think we have escaped the bad old world of scientific 'prediction and control'. If it is true that our understanding of human action, including our own action, is always mediated, then we have to ask in what ways the idea that people should speak about their experiences to researchers in psychology is itself already mediated, already operates within a particular series of mediations, social structures.

The hope of many qualitative researchers now is that in their interviews they will be able to get their participants to really tell them their stories. Discursive psychologists have helped us to see what the early 'new paradigm' researchers insisted from the beginning, that the telling of a story is an account performed within certain sets of roles and rules for the researcher (Potter, 1998). And even the fiction that 'naturally-occurring conversation' is a spontaneous production is deconstructed as the analyst uncovers the rhetorical devices that necessarily structure it.

What Foucault shows us is that there are not only obviously coercive procedures that rely on the old laboratory-experimental 'prediction and control' of behaviour, the kind 
of thing that he wrote about in Discipline and Punish as study of the birth of modern prison regimes (Foucault, 1976). There is also an increasingly powerful shadow-side to power in the incitement to speak the truth of one's experience or identity to a professional which he writes about in The History of Sexuality Volume I (Foucault, 1981).

Many qualitative researchers in psychology today seem to have bought into what Foucault calls 'the repressive hypothesis', which is the idea that power held things down, and now we have the freedom to speak, and so we must. Our participants must speak to us, and we must speak reflexively about our experience of them speaking to us, and so we are caught in a vicious spiral of confession which pretends to reveal what is interior to each of us. This assumption surreptitiously installs a particular version of humanist deep subjectivity as an ideal which, we are invited to imagine, would be terrible and pathological to refuse to conform to.

What must you be like to speak? This raises a third issue which concerns a dimension of power that Foucault was not so attentive to, which is how gender is reconfigured as a source for new research but then also as a threat to mainstream psychology. From being an object of psychological research in old studies of so-called 'sex differences', women find a voice in the new paradigm, but not in conditions entirely of their own choosing. The organisation inside the British Psychological Society (BPS) which has provided a space for feminist arguments is still, for example, called the 'Psychology of Women' section.

So on the one hand involvement of women is seen as a threat. A guest interview published without any editorial disclaimer in the December 2012 issue of The Psychologist, which is the house organ of the BPS repeated an oft-rehearsed claim that psychology has moved in a 'female' direction and so it is now 'less balanced' than it was before. The interview with a past-President of the BPS claimed that psychology is now 'seen as mainly suitable for women', and suggested that it would be better for a new department founded today to call itself 'behavioural sciences' (Radford, 2012, p. 913).

On the other hand, some of the best research in the qualitative tradition was made possible by the new paradigm arguments drew upon the historically-constituted stereotypical attributes of women - attention to emotion, intuitive relational awareness, sense of embodiment - to craft accounts from interviews and diaries (e.g., Hollway, 1989). An early 'handbook' of new paradigm research (Reason and Rowan, 1981, p. xxii) shamefacedly confessed the absence of contributions by women, but this was precisely because the space that had been opened up has become comparatively gender-sensitive and even in some places feminist-friendly.

In sum, it would be more accurate to refer to these developments as new paradigm 'reforms' rather than revolution, and in the most part these reforms have had the effect of recuperating - that is, neutralising and absorbing - the most radical arguments made against psychology. Qualitative research must play the rules of the game, and it has actually proved very useful in helping psychology itself adapt to new political-economic conditions, enabling psychology to reach the parts that it could not reach before and accelerating a more general psychologisation of contemporary society (De Vos, 2012). This brings us to the question of neoliberalism.

Neoliberalism and 'gender' 
Capitalism in its first hundred years or so was characterised, among other things, by a separation of men and women and their allocation to specific gender roles. That separation and allocation produces, and reproduces we might say, a division of attributes and experiences, between, on the one hand, pleasing and caring which takes place in the home, and, on the other hand, prediction and control which takes place in the workplace (Zaretsky, 1976). This process then naturalises gender and covers over the fact that, for example, in Manchester during the first industrial revolution the textile workers were mainly women and mainly working from home (and, not incidentally, were mainly Irish immigrants) (Marcus, 1974).

Then something dramatic happens after the Second World War with the rise of the service-sector - hotels and catering, leisure industries, logistics - and what some theorists described as an electronic third industrial revolution (after those powered by steam and electricity) that gave rise to 'late capitalism' (Mandel, 1974) and that others then thought to provide the material basis of postmodernism as the cultural logic of late capitalism (Jameson, 1984). This brings millions of women back into the workplace, and it harnesses skills women practised in the home.

This is the world that Arlie Hochschild (1983) describes in her book The Managed Heart in the early 1980s, and her book's subtitle 'the commercialisation of human feeling' sums up the way that affect is brought into the work-place and put to use there. Not only does a woman sell their labour power when they go to work, they sell their capacity to engage in 'emotional labour'. Commitment to the product must be felt, or performed as felt at some depth, and commitment to customer satisfaction all the more so. Alienation at work is thus given another twist as a result of the 'deep acting' expected of employees.

Hochschild's account is Marxist, something that has tended to be obscured in much academic discussion of her work but which still needs amplification (Brook, 2009). For Marx (1844), alienation under capitalism is four-fold: there is alienation of each individual from the others as competition for resources is reconfigured as competition for work; there is alienation from one's own nature as it become imperative that the body is maintained and capable of work; there is alienation from nature as such when it is turned into something that is turned into exploitable resource; and there is alienation in the most-well-known classical sense as division in the human subject as they are separated from the products of their own creative activity. Deep acting bears on each of these aspects, but also eats away at the personal and collective space that we need to be able to step back and reflect on what is going on.

And this emotional labour becomes the template for how all employees should perform at work, not only women. For example, the fast-food sandwich chain Pret a Manger specifies three core 'Pret Behaviours' it wants to see in employees, 'Passion, Clear Talking and Team Working'. Its chief executive says that the first thing he looks at when he visits a store 'is whether staff are touching each other - are they smiling, reacting to each other, happy, engaged? Look, she's just touched her colleague - squeezed her arm. If I see hands going up in the air, that's a good sign. I can almost predict sales on body language alone' (Preston, 2012).

Meanwhile the company is cracking down on attempts to set up a staff trade union, and dismissed one of its activists (a student from the Czech Republic) two weeks after the union was formed in September 2012. A statement on the Pret website claims that the dismissal is for 'misconduct', because the activist had 'made homophobic comments to a colleague' back in December 2011 (Myerscough, 2013). Maybe it is true, maybe he had 
made such comments, but it also indicates something of the sensitivities that a company might employ and exploit in its own management of affect. It includes 'feelings' in its work, and it will exclude those who hurt the feelings of others, and it does this in a quite different way, according to a quite different agenda, than the attention to the 'personal' affective aspects of politics in the socialist feminist tradition (Rowbotham et al., 2013).

Evidently something nastier than the recruitment of more women and a kind of 'turn to affect' in the service sector has taken place here. We have some indication of what is going on in the attempt to stop collective trade union activity and target individuals, and in the precarious life of a migrant labour force living under threat of unemployment. That something nastier is neoliberalism, and there are two faces of neoliberalism that we need to take seriously.

Freedom of the individual The first is deregulation and privatisation. That is, there is lifting of state restriction on activities of companies, and the handing over of health and welfare provision to the private sector. The deregulation and privatisation goes hand in hand. There is dismantling of state provision of essential services as well as of collective governance of society which might mitigate the worst of exploitation, even if imperfectly and bureaucratically handled. And there is a material and ideological shift of emphasis to the domain of the individual, to individuals as responsible for protecting themselves.

Neoliberalism is not merely a theory about the management of capitalism. It is a mode of operation of capitalism in its most brutal form, a return to capitalism imagined by the classical liberal nineteenth-century economists. Restrictions are lifted on the market as medium of social relations so that human beings are turned into objects, commodities, and now they turn not only their own nature into objects - one of the four aspects of alienation described by Marx - but what they imagine to be their 'feelings'.

At work here is the fantasy of untrammelled competition, of freedom from state interference. This mode of capitalism comes into its own with the collapse of the Soviet Bloc and now China as spaces of political-economic organisation ostensibly outside capitalism (Loong-Yu, 2012). That itself was an ideological fantasy in the West with its own powerful effects, and the place of 'neoliberalism' as a reified discourse itself needs to be culturally contextualised as part of the apparatus of power (Kipnis, 2007). One of the characteristics of neoliberalism is that it dismantles barriers between nation states. In this respect neoliberalism now is one of the names of globalisation.

Power of the State The other face of neoliberalism, however, is just as important, that of surveillance and state power. The first great neoliberal experiment was in the first terrible ' $9 / 11$ ' of the Americas. Most people in the global north will associate 11 September with the attacks on the World Trade Center, but 11 September was also the date of the CIA-backed Pinochet coup in Chile in 1973 which resulted in over 3,000 dead and millions ripe for trying out the ideas of the Chicago School economists. These are events well-described by Naomi Klein (2008) in The Shock Doctrine, and she shows how the rise of what she calls 'disaster capitalism' relies on the destruction of natural and human resources so that the ground can be cleared and rebuilt from zero.

Under the Allende government, attempts were made to develop advanced cybernetic planning which would also be democratic, an aspect of so-called 'state control' that is obscured today by neoliberal commonsense that is predicated on the idea that State planning as such is bad and the individual is good (Medina, 2012). It is a measure of the 
power of ideology that we should buy this assumption and overlook the role of the State in regulating and enabling capitalism right from its early years to contemporary neoliberalism.

An intriguing and telling metaphorical trope that guides Klein's book is that of 'shock' conceived as a form of trauma which not only physically destroys the existing material and symbolic field of action for capitalism but which overwhelms those subject to it so they are unable to organise collectively or fight back. The destruction is a tragedy and an opportunity, and economic policy 'shock therapy' administered to make people work is the least of it.

In Klein's account we can see a theory of what the human psyche is like which she deploys to make sense of how societies are broken down and rebuilt, and her account corresponds quite well to a world that is increasingly psychologised, in which its inhabitants account for their 'feelings' as gauges and drivers of their behaviour (De Vos, 2012). The point is not that Klein is 'psychologising' - though she is doing that - but that her account captures well what is going on. We should at this point recall Sohn-Rethel's (1978) point about the 'necessary false consciousness' we need to survive under capitalism.

The fantasy of the classical liberal economists who aimed to unshackle the market and let entrepreneurs roam free was that the State was an impediment to the development of capitalism. In reality the companies will combine into cartels, and the free market will seize up if there is no State intervention. And the biggest lesson of the 1973 neoliberal experiment was that you need an incredibly vicious strong State if you want this form of capitalism to thrive. And even this it did not, on its own terms, work (Petras and Vieux, 1990).

For this to appear to work you need to intimidate as well educate people into the ways of the market, into obedience to the market, and as part of that process there needs to be intervention into the realm of education itself. Chile also provides an example, by the way, of how education as an 'Ideological State Apparatus' in Louis Althusser's (1971) use of the term is a machinery not only of interpellation of individual subjects but also of terror.

\section{Managing subjectivity}

In the years of the dictatorship psychology was under suspicion as being a little too close to sociology, which was intolerable to the regime. However in the later years of Pinochet's rule the neoliberal experiment extended to the deregulation and privatisation of higher education and private universities were permitted to run radical, even Marxist psychology courses. After all, this was the logic of the argument that the market should decide. Now there is incredible competition in Chile between universities for students at the beginning of each academic year, and the student movement has been protesting against education run for profit (Rojas, 2012).

'Where there is power, there is resistance' it has been said (Foucault, 1981, p. 95), but before we get to the resistance we need to say something about forms of power in this particular matrix I have described so far. To do this, I need to focus for a moment on some case examples.

Britain is experiencing some dramatic changes in higher education with the introduction of student fees under the last Labour government and then, in line with Blair's reforms which reduced government funding for courses, tripling of fees to $f 9,000$. This has led to some degree of panic among universities chasing the student fees, and panic over the 
public metrics or 'Key Performance Indicators' (KPI) that parents even more than prospective students will use to choose a course.

A regular 'National Student Survey' (NSS) which is supposed to measure the level of 'satisfaction' with a course has become an obsession for university vice-chancellors, and the pressure is relayed to lecturing staff via Deans of Faculty and Heads of Department (McGettigan, 2013). Departments that are 'red-lighted' are told they could be closed, and the scene is set for harassment of researchers who are seen as wasting everyone's time and money rather than contributing to the 'student experience' in class and for bullying of lecturers who are not as efficient or entertaining as they should be.

I want to focus on four aspects of this management of subjectivity: experience, rhetoric, affect and self-abasement.

Experience Perhaps 'experience' becomes important not only because qualitative research in psychology values experience but, more importantly, because neoliberal management comprises a weird dialectic of secrecy and transparency.

Ros Gill (2010) has written, for example, about the 'hidden injuries' of the neoliberal university, drawing attention to levels of anxiety and stress that are experienced at the level of the individual lecturer and researcher who are separated from colleagues in contemporary 'audit culture' (Strathern, 2000). The point here is that this 'audit culture' operates as a mode of surveillance of individual performance that is ostensibly 'transparent' but is actually deeply mystifying to those who are subject to it. The conditions for this kind of audit are secrecy and control rather than openness and participation.

Rhetoric Just as there has been a 'turn to discourse' in psychology (and as one resource for 'critical psychology'), so there has also been a 'turn to discourse' in management, management discourse which encloses and neutralises critical discourse.

That there should be deception here is not really surprising, for neoliberal management discourse itself operates as a form of deception. Chris Lorenz (2012) sums it up like this in his review of the way neoliberal universities exemplify a regime of 'New Public Management' (NPM) which combines free market rhetoric with an 'unprecedented network of controls': 'NPM policies employ a discourse that parasitizes the everyday meanings of their concepts - efficiency, accountability, transparency, and (preferably excellent) quality and simultaneously perverts all their original meaning' (Lorenz, 2012, p. 600).

As Lorenz (2012, p. 618) points out 'Professional autonomy then appears - mirabile dictum - as irresponsible and elitist, while the subordination of professionals in top-down managerial control systems is presented as increased accountability and as democratic'. This, he writes, is not exactly 'lying' because it does not refer to the truth as such. Rather, it is rather like the ideal-typical performative and pragmatic world of some discourse analysts. It appears in the language of 'systematic review' in research (MacLure, 2005). It is what Harry Frankfurt (2005, p. 34) calls 'bullshit': The bullshitter 'does not reject the authority of the truth, as the liar does, and oppose himself to it. He pays no attention to it at all. By virtue of this, bullshit is a greater enemy of the truth than lies are.

But as we have seen, it is difficult to live inside this, to experience oneself as agent in a system of discourse that treats you like a piece of shit without there being some strong affect. And affect, as we know, is intimately linked to gender in patriarchal capitalist society. 
Affect The management of subjectivity includes management of affect, not only to manage woman as the traditional stereotypical sites of affect but also by way of the recruitment of women as managers to more effectively include 'affect' in their armoury of control.

Women managers in psychology who want to get on in this world are told, for example, to use adjectives and action verbs in their job applications, and to demonstrate emotional competencies: 'Those who demonstrate emotional competencies - selfawareness, social awareness, self-management, relationship management - advance more in their careers'.

(http://www.thepsychologist.org.uk/blog/blogpost.cfm?catid=48\&threadid=2152, accessed 2 February 2013). This is a use of the notion of 'emotional literacy' that has actually been critiqued in feminist research (Burman, 2009).

In fact, the position of women at work is not necessarily enhanced by this. It turns out that men who are able to learn how to perform their affective engagement with customers and employees will be the ones who are still more likely to rise to the top of organisations. Notwithstanding some changes in forms of masculinity in recent years, men are still in command, and these changes tend to complement and even facilitate male power (Segal, 2006). Women are far more likely to be at the sharp end of this process, more indebted from university fees, getting less pay than their male colleagues in Higher Education in general, and more likely to be part of the precarious workforce that is on shortterm contracts. These changes may constitute the 'feminisation' of work, but it became clear very soon that this is very different from feminism as such, even if some kinds of feminist discourse might at times be useful for an organisation to warrant it.

Gender itself then becomes a discursive resource to humiliate those who do not fit in. For example, comments were made to other female staff by a new head of department in one university about one male lecturer whom she saw as not behaving well that 'I know how to deal with men who live with their mothers'. In a departmental meeting later on she said to this lecturer who arrived late, while she was patting the chair seat, 'there is a place here next to me, it isn't contaminated'. He obeyed, and was later promoted.

These discursive operations, and the disconnection of discourse from one reality to be embedded in neoliberal institutions, are given particular force by the threat if you do not obey you will be subject to a disciplinary procedure and may lose your job.

Self-abasement One response to this is the anxiety and stress that Ros Gill (2011) writes about, another is cynical endorsement by managers and their subordinates when they circulate this discourse without really believing it themselves. Another, worst perhaps, response is what the theologian Richard Roberts (2012) calls 'sacrifice of the self', a 'performative absolute' which is 'an all-consuming, all-seeing, yet self-concealing power that feeds on identity, which it digests and then regurgitates as transformation and personal development into those held within its power' (Roberts, 2012, p. 18).

What Roberts could do here is show how notions of femininity are deployed as part of this 'self-concealing power that feeds on identity', and then we would be in the domain of debates about what is sometimes called 'femocracy', and over whether the recuperation of women into management positions is really transforming the way that neoliberal organisations operate (e.g., Ashcraft, 2006).

The institutional changes that are taking place in higher education as a neoliberal agenda is enforced by management make use of women, but do not benefit them. The competitive ethos that is intensified by these changes is actually stereotypically masculine, 
and it is men who still remain in senior managerial positions making middle-level woman managers do their emotional dirty work; under these conditions there is a 'punitive psychosocial logic' which can be 'routinely and expansively stimulated by threat and inducement' (Hey, 2011, p. 209). The combination of stress, cynicism, affect and self-abasement that these neoliberal conditions call for is, of course, anathema to scholarship, to the conditions that need to do anything like 'critical psychology'. Rather, it looks rather like the most paranoiac vision that we sometimes conjure up in our writing about psychology itself.

\section{Conclusions}

One of the most bizarre charges made against me during the course of the disciplinary investigation was by my Head of Department, that lan Parker is, and I quote, 'a use of language expert and his assertions are made in ways that capitalise on this expertise'. This claim does, of course, deploy a version of that old notion that because we are psychologists we know what you are thinking. It adds on to this the idea that to be an expert in discourse analysis, which I am not, is to be able not only to read texts but to write them. This is psychologisation with a twist; not only is what we know about psychology made part of the apparatus of power, but what we know about discourse is psychologised, at the very same moment as discourse becomes part of the apparatus of power.

It is small comfort that the world of psychology as we described it has come to pass in the very institutions we work in. What is most worrying, and no comfort at all, is that 'affect' is chained to gender in discourse so that the very quantification of experience that the university relies on to perform and compete in the market-place requires a qualitative dimension. It as if the conceptual resources we once used as critique have been sucked into the apparatus and are now used to interpellate and interpret us. If complaints were once made that Althusser was a 'philosopher of order' (Rancière, 2011), they also seem to have come true now.

A key aspect of 'critical psychology' is that we turn the gaze of the discipline, which is usually focused on the outside world as if that was the world of non-psychologists, back onto psychology itself. And when we turn that gaze back on our institutions, we need to include in our critical work, critique of the recuperation of elements of critical psychology itself. Much 'critical psychology', even in its most 'social' variants can be more easily recuperated if it is viewed as a merely academic alternative or complement to mainstream research, and this means that when we do think of ourselves as 'critical' we also need to think about the institutional role that mainstream and critical theories and methodologies play (Parker, 2007).

We do not put all our bets on qualitative or discursive approaches, and we for sure do not put all our bets on psychology. 'Psychology' is not our identity, and the audiences to which we are accountable might include communities, psychology service users, trades unions, and broader progressive political traditions; perhaps Marxism, and certainly feminism (Rowbotham et al., 2013), perhaps in alliance with Marxism (Arruzza, 2013), but always something beyond the discipline. And it is from that vantage point that we appreciate that there are still spaces where we can do our critical work, and know why we need to defend them and make the most of them.

\section{Note}


I would like to thank anonymous reviewers of a draft paper for their helpful and sharp comments. I dedicate this paper to Erica Burman, now Professor of Education at the University of Manchester, whose own story about the difficult events described here has yet to be told to you.

\section{References}

Althusser, L. (1971) Lenin and Philosophy, and Other Essays. London: New Left Books.

Ashcraft, K. (2006) 'Feminist-bureaucratic control and other adversarial allies: Extending organised dissonance to the practice of "new" forms', Communication Monographs, 73, (1), pp. 55-86.

Arruzza, C. (2013) Dangerous Liaisons: The Marriages and Divorces of Marxism and Feminism. London: Merlin.

Banister, P., Burman, E., Parker, I., Taylor, M. and Tindall, C. (1994). Qualitative Methods in Psychology: A Research Guide. Buckingham: Open University Press.

Banister, P., Bunn, G., Burman, E., Daniels, J., Duckett, P., Goodley, D., Lawthom, R., Parker, I., Runswick-Cole, K., Sixsmith, J., Smailes, S., Tindall, C. and Whelan, P. (2011) Qualitative Methods in Psychology: A Research Guide (Revised $2^{\text {nd }}$ Edition). Buckingham: Open University Press.

Brook, P. (2009) 'The Alienated Heart: Hochschild's "emotional labour" thesis and the anticapitalist politics of alienation', Capital \& Class, 33, (7), pp. 7-31.

Burman, E. (ed.) (1990) Feminists and Psychological Practice. London: Sage.

Burman, E. (ed.) (1998) Deconstructing Feminist Psychology. London: Sage.

Burman, E. (2009) 'Beyond "emotional literacy" in feminist and educational research', British Educational Research Journal, 35, (1), pp. 137-155.

Callinicos, A. (2006) Universities in a Neoliberal World. London: Bookmarks.

Collins, P. H. (2000) Black Feminist Thought: Knowledge, Consciousness, and the Politics of Empowerment ( $2^{\text {nd }}$ Edn). London and New York: Routledge.

De Vos, J. (2012) Psychologisation in Times of Globalisation. London: Routledge.

Dreyfus, H. and Rabinow, P. (1982) Michel Foucault: Beyond Structuralism and Hermeneutics. Brighton: Harvester Press.

Du Bois, W. E. B. (1994) The Souls of Black Folk. New York: Gramercy Books.

Ellis, C. and Bochner, A. P. (2000) Autoethnography, personal narrative, reflexivity, in N. K. Denzin and Y. S. Lincoln (eds) Handbook of Qualitative Research, $2^{\text {nd }}$ edn. Thousand Oaks, CA.: Sage.

Feyerabend, P. (1978) Against Method: Outline of an Anarchistic Theory of Knowledge. London: Verso.

Foucault, M. (1976) Discipline and Punish: The Birth of the Prison. London: Allen Lane.

Foucault, M. (1981) The History of Sexuality, Vol. I: An Introduction. Harmondsworth: Pelican.

Frankfurt, H. (2005) On Bullshit. New York: Princeton University Press.

Gill, R. (2010) 'Breaking the Silence: The Hidden Injuries of the Neoliberal University', in R. Flood and R. Gill (eds) Secrecy and Silence in the Research Process: Feminist Reflections (pp. 228-244). London: Routledge.

Gough, B., McFadden, M., and McDonald, M. (2013) Critical Social Psychology: An Introduction ( $2^{\text {nd }}$ Edition). London: Palgrave. 
Hammond, K. (1998) 'Ecological validity: Then and now', http://www.albany.edu/cpr/brunswik/notes/essay2.html (accessed 2 February 2013).

Harré, R. and Secord, P. (1972) The Explanation of Social Behaviour. Oxford: Blackwell. Hepburn, A. (2002) An Introduction to Critical Social Psychology. London: Sage.

Hey, V. (2011). Affective asymmetries: Academics, austerity and the mis/recognition of emotion', Contemporary Social Science, 6(2), 207-222.

Hilgard, E. (1977) Divided Consciousness: Multiple Controls in Human Thought and Action. New York: Wiley.

Hochschild, A. R. (1983) The Managed Heart: Commercialisation of Human Feeling. Berkeley, CA: University of California Press.

Jameson, F. (1988) The Ideologies of Theory: Essays 1971-1986. Minneapolis: University of Minnesota Press.

Kipnis, A. (2007) 'Neoliberalism reified: Suzhi discourse and tropes of neoliberalism in the People's Republic of China' Journal of the Royal Anthropological Institute, 13, pp. 383-400.

Klein, N. (2008) The Shock Doctrine: The Rise of Disaster Capitalism. Harmondsworth: Penguin.

Kuhn, T. (1962) The Structure of Scientific Revolutions. Chicago: University of Chicago Press. Leadbeater, C. (2000) Living on Thin Air: The New Economy. Harmondsworth: Penguin.

Levidow, L. (2002) 'Marketizing Higher Education: Neoliberal Strategies and Counterstrategies', in K. Robins and F. Webster (eds.) The Virtual University? Knowledge, Markets and Management (pp. 227-248). Oxford, UK: Oxford University Press.

Loong-Yu, A. (2012) China's Rise: Strength and Fragility. London: Resistance Books.

Lorde, A. (2007) Sister Outsider: Essays and Speeches. Darlinghurst, New South Wales: Crossing Press.

Lorenz, C. (2012) 'If You're So Smart, Why Are You under Surveillance? Universities, Neoliberalism, and New Public Management', Critical Inquiry, 38, (3), pp. 599-629.

Lynch, K. (2006) 'Neo-liberalism and Marketisation: The Implications for Higher Education', European Educational Research Journal, 5, (1), pp. 1-17.

MacLure, M. (2005) "Clarity bordering on stupidity": Where's the quality in systematic review?', Journal of Education Policy, 20, (4), pp. 393-416.

Mandel, E. (1974) Late Capitalism. London: New Left Books.

Marcus, S. (1974) Engels, Manchester, and the Working Class. New York: W. W. Norton.

Marx, K. (1844) 'Economic and Philosophical Manuscripts', in New Left Review (ed.) (1975) Karl Marx: Early Writings (pp. 279-400). Harmondsworth: Pelican.

Masterson, M. (1970) 'The Nature of a Paradigm', in Lakatos, I. and Musgrave, A. (eds.) Criticism and the Growth of Knowledge. Cambridge: Cambridge University Press

McGettigan, A. (2013) The Great University Gamble: Money, Markets and the Future of Higher Education. London: Pluto Press.

Medina, E. (2012) Cybernetic Revolutionaries: Technology and Politics in Allende's Chile. Cambridge, MA: MIT Press.

Myerscough, P. (2013) 'Short Cuts', London Review of Books, 3 January, p. 25.

Neisser, U. (1976) Cognition and reality. San Francisco: W. H. Freeman and Co.

Parker, I. (2007) Revolution in Psychology: Alienation to Emancipation. London: Pluto.

Parker, I. (ed.) (2011) Critical Psychology (Four-Volumes). London and New York: Routledge. 
Pavón Cuéllar, D. (2010) From the Conscious Interior to an Exterior Unconscious: Lacan, Discourse Analysis and Social Psychology. London: Karnac.

Petras, J. and Vieux, S. (1990) 'The Chilean "economic miracle": An empirical critique', Critical Sociology, 17, pp. 57-72.

Potter, J. (1998) 'Fragments in the realization of relativism', in I. Parker (ed.) Social Constructionism, Discourse and Realism. London: Sage.

Preston, R. (2012) 'Smiley culture: Pret A Manger's secret ingredients', The Telegraph, 9 March, http://www.telegraph.co.uk/foodanddrink/9129410/Smiley-culture-Pret-AMangers-secret-ingredients.html (accessed 22 January 2013).

Radford, J. (2012) 'Adapt or perish - understand ourselves', The Psychologist, 25, (12), pp. 912-913.

Rancière, J. (2011) Althusser's Lesson. London: Continuum.

Reason, P. and Rowan, J. (eds.) (1981) Human Inquiry: A Sourcebook of New Paradigm Research. Chichester: Wiley.

Roberts, R. (2012) 'Contemplation and the "Performative Absolute": Submission and identity in managerial modernity', Journal of Management, Spirituality and Religion, 9, (1), pp. 9-29.

Robertson, R. (1995) 'Glocalization: Time-space and homogeneity-heterogeneity', in M. Featherstone, S. Lash and R. Robertson (eds) Global Modernities (pp. 25-44). London: Sage Publications.

Rojas, R. (2012) 'Return of the Penguins!', International Viewpoint, 446, http://www.internationalviewpoint.org/spip.php?article2530 (accessed 2 February 2013).

Rowbotham, S., Segal, L. and Wainwright, H. (2013) Beyond the Fragments: Feminism and the Making of Socialism. London: Merlin.

Segal, L. (2006) Slow Motion: Changing Masculinities, Changing Men ( $3^{\text {rd }}$ Edition). London: Palgrave.

Sohn-Rethel, A. (1978) Intellectual and Manual Labour: A Critique of Epistemology. London: Macmillan.

Strathern, M. (2000) 'The tyranny of transparency', British Educational Research Journal, 26, pp. 309-321.

Torres, C. and Schugerensky, D. (2002) 'The Political Economy of Higher Education in the Era of Neoliberal Globalization: Latin America in Comparative Perspective, Higher Education, 43, pp. 429-455.

Zajda, J. (Ed.) (2005) International Handbook on Globalisation, Education and Policy Research: Global Pedagogies and Policies. Dordrecht, Netherlands: Springer.

Zaretsky, E. (1976) Capitalism, the Family, and Personal Life. London: Pluto Press. 